Illinois State University

ISU ReD: Research and eData

Theses and Dissertations

$5-8-2020$

\title{
An Action Research Study On The Use Of Flipped Learning In A Spanish As A Foreign Language Class
}

Juan Carlos Acevedo Fontecha

Illinois State University, juanbond37@hotmail.com

Follow this and additional works at: https://ir.library.illinoisstate.edu/etd

Part of the Instructional Media Design Commons, Linguistics Commons, and the Teacher Education and Professional Development Commons

\section{Recommended Citation}

Acevedo Fontecha, Juan Carlos, "An Action Research Study On The Use Of Flipped Learning In A Spanish As A Foreign Language Class" (2020). Theses and Dissertations. 1258.

https://ir.library.illinoisstate.edu/etd/1258

This Thesis is brought to you for free and open access by ISU ReD: Research and eData. It has been accepted for inclusion in Theses and Dissertations by an authorized administrator of ISU ReD: Research and eData. For more information, please contact ISUReD@ilstu.edu. 
AN ACTION RESEARCH STUDY ON THE USE OF FLIPPED LEARNING IN A SPANISH

AS A FOREIGN LANGUAGE CLASS

\section{JUAN CARLOS ACEVEDO FONTECHA}

56 Pages

The present action research evaluated the teacher's perception and the students' attitudes and practices over the impact of applying a flipped learning model for a basic Spanish course. Unlike previous studies that have evaluated the model considering students' perceptions and language performance, this study also considered the teacher in a cyclical process of using the flipped model. The intervention consisted of four classes that dealt with grammar topics transferred into tutorial videos and in-class activities to practice the content from the videos. To gain a broader spectrum of the teacher's perception, this study used questionnaires, and field journals designed to obtain both numerical and non-numerical data from the teacher and the students. Although several inadequacies influenced in the implementation of the flipped model, this action research highlighted the process of implementing a new model and the cyclical phases. The results from the study indicated that assignment completion is pivotal for the model to work. Additionally, when the flipped model is implemented properly, the role of the teacher is more of a facilitator. The Q\&A session suggested by the model helps to discuss and build grammar knowledge in a bidirectional way between students and teacher.

KEYWORDS: flipped model; flipped classroom; flipped learning; action research; language learning 
AS A FOREIGN LANGUAGE CLASS

JUAN CARLOS ACEVEDO FONTECHA

\author{
A Thesis Submitted in Partial \\ Fulfillment of the Requirements \\ for the Degree of \\ MASTER OF ARTS \\ Department of Languages, Literatures, and Cultures \\ ILLINOIS STATE UNIVERSITY
}


Copyright 2020 Juan Carlos Acevedo Fontecha 
AN ACTION RESEARCH STUDY ON THE USE OF FLIPPED LEARNING IN A SPANISH

AS A FOREIGN LANGUAGE CLASS

JUAN CARLOS ACEVEDO FONTECHA

COMMITTEE MEMBERS:

Mir Monserrat, Chair

Susan Hildebrandt

Rachel Shively 


\section{ACKNOWLEDGMENTS}

I want to offer this endeavor to God for letting me find the physical and human resources, as well as the time to complete this project during the covid-19. I also wish to acknowledge the support and great love of my wife, Rocio, my daughter Amelie and my mother, Lilia, who always offered me a word of encouragement. Finally, I wish to express my appreciation to my supervisor, Dr. Monserrat Mir, who guided, encouraged, and supported me before and during this project and my master's program.

J.C.A.F. 


\section{CONTENTS}

Page

ACKNOWLEDGMENTS

$\begin{array}{ll}\text { CONTENTS } & \text { ii }\end{array}$

TABLES $\quad$ iv

FIGURES

CHAPTER I: INTRODUCTION 1

CHAPTER II: LITERATURE REVIEW

Communication in language teaching today 3

Flipped classroom history $\quad 9$

Research on the flipped classroom $\quad 12$

Research on the flipped foreign language classroom 13

$\begin{array}{ll}\text { Action research } & 17\end{array}$

$\begin{array}{ll}\text { CHAPTER III: METHODOLOGY } & 21\end{array}$

$\begin{array}{ll}\text { Participants } & 21\end{array}$

$\begin{array}{ll}\text { Teaching context } & 21\end{array}$

$\begin{array}{ll}\text { Data collection instruments and procedures } & 22\end{array}$

$\begin{array}{ll}\text { TR's survey } & 22\end{array}$

$\begin{array}{ll}\text { Students' survey } & 23\end{array}$

$\begin{array}{ll}\text { Data analysis } & 23\end{array}$

CHAPTER IV: FINDINGS AND INTERPRETATION 26

$\begin{array}{ll}\text { Lesson 1: irregular preterit tense (week 7) } & 27\end{array}$

Lesson 2: direct and indirect object pronouns (week 8) 30 
Lesson 3 imperfect tense (week 9)

Lesson 4 impersonal "se" (week 11)

What are the students' perceptions and attitudes toward flipped learning?

How does the flipped classroom impact teacher's philosophy of teaching and teaching practices?

CHAPTER VI: CONCLUSIONS

REFERENCES 


\section{TABLES}

Table

$1 \quad$ Class time for traditional vs. flipped classroom by Bergmann and Sams 10

2 The four lessons selected to implement the flipped model 25

3 Video-related questions $\quad 30$

$4 \quad$ Completion of assigned activities outside the classroom 38 


\section{FIGURES}

Figure

1 Systematic inquiry based on ongoing reflection (Hendricks, 2006, p. 18) 19

2 Sample of MSL's activity and tools to help 24

3 Teacher's perceptions of the flipped vs non-flipped classroom 26

4 Sample after the first attempt of an online exercise 29

5 Q\&A slide used in class 31

6 Lesson 2, students' survey “usefulness of video and MSL activities 32

7 Session 3, Students' survey "reasons for not watching the video 35

8 Sample of a humorous activity for lesson four 36

9 Session 4, students' survey “usefulness of video and worksheet activities 37 


\section{CHAPTER I: INTRODUCTION}

It has been almost a decade with the flipped classroom model, and research on the model framework is still limited (Clark, 2015). Methods have adapted to the new technological advancements to become part of the classroom setting and the flipped model responds to these new ways of teaching and studying (Bergmann \& Sams, 2012). This model moves the direct instruction into videos, and out of the classroom setting to an individual learning space. Class time is used to answer students' questions and practice new concepts. This model first gained popularity in STEM subjects (science, technology, engineering, and math), but eventually, it reached nonSTEM disciplines. However, in the humanities disciplines, the idea of assigning readings as homework and using time in class to discuss concepts and themes has been the norm (Gaughan, 2014). In second/foreign language courses, a flipped model, which claims to reduce lecture time, may not make more sense considering that language classroom does not promote extensive lecturing when compared to STEM (Berret, 2012). At first glance, this model does not offer much to language courses. Nevertheless, some research in foreign languages has shown some benefits of using a flipped model such as positive learning environments and better grades compared to regular classes (Oki, 2016). The limited amount of research in foreign language teaching contexts has partly motivated this current study.

It has been argued that the flipped model seems to have positive results in students' outcomes or scores when compared with the regular class (e.g., Al-Harbi, 2016; Kang, 2015; Moranski \& Kim, 2016). In addition, students have perceived as positive the in-class performance and, outside and in-class activities (e.g., Basal, 2015; and Kang, 2015). While many studies have claimed that the flipped model positively enhances students' performance, some have revealed that the influence on students' performance is still debatable (Oki, 2016). Today research in flipped 
learning is abundant but many studies have focused on exploring differences in academic performance between a flipped learning environment and a traditional teaching context. To the author's knowledge, very little research exists that looks at the process of implementing a flipped model from the teacher's perspective as well as students' perceptions. In order to explore this new venue of examining flipped learning, the teacher-researcher (TR) for this study engaged in an action research (AR) investigation. Action research was used as the method to examine flipped learning because this type of research permits to continually observe the students, collect data, and change practices (Mills, 2011). The objective of this investigation is to examine and evaluate the process of implementing a flipped model in four Spanish language lessons at the university level by exploring changes in teacher's and students' perceptions, attitudes, and practices. 


\section{CHAPTER II: LITERATURE REVIEW}

In this chapter, we discuss four major themes which emerge repeatedly through the study of the flipped model; communication in language teaching, a brief history of the flipped classroom, some of the general research done over the flipped model, and some specific research done over the flipped foreign language classroom. This chapter also includes the type of research that considers the teacher as an active role in the process of investigation, action research.

\section{Communication in language teaching today}

Bergmann and Sams (2017) define flipped learning as an instructional model in which direct instruction is delivered individually through videos. The authors insist that the time gained from the videos frees up face to face time for meaningful learning experiences. However, approaches and methods in language instruction have aimed to increase time for interaction and learning experiences too. The expectation for education is high, and no matter how much is achieved, society continues to expect even more (Woolf et al., 2013). Rapid changes in our society have given the opportunity for new methods to emerge as it is the case for the flipped model. The foundations of the methods we have today evolved from first language learning theories in the past. These theories highlighted the importance of learners' interaction with objects and things (Piaget, 1951), the role of the environment in the learning process (Chomsky, 1959), or the need for positive reinforcement to encourage children (Skinner, 1957), just to mention some. Many of these theories are part of more current methods, approaches, techniques, and models of teaching that recognize the role of communication in language teaching today.

Communicative language teaching (CLT) is an approach that responds to the primary function of language that is communication (Brandl, 2008). The goal of this approach is to develop communicative competence for language learners. This competence allows the student to use the 
language considering the rules dictated by the language and society. Communicative competence includes four components: the linguistic competence or the knowledge of vocabulary and grammar; the sociolinguistic competence that has to do with saying the right thing in the appropriate social situation; the ability to start, enter, contribute and end a conversation in a coherent manner or the discourse competence; the strategic competence that involves the ability to communicate effectively and repair problems caused by breakdowns (Brandl, 2008). The teaching practices in a CLT class focus on the development of these competencies by encouraging the use of real-life situations in interactions that encourage the production and negotiation of personal meaning between individuals. CLT emphasizes the functional use of languages for meaningful purposes, and consequently, learning grammar rules or vocabulary lists are relegated to a secondary role.

Another teaching approach that has communication and language proficiency at its core is task-based instruction (TBI). Within this approach, the task is the primary focus of the lesson and language is the instrument to complete that task. The following definition of a task by Nunan (2004) encompasses the foundation of a task.

Task is a piece of classroom work that involves learners in comprehending, manipulating, producing or interacting in the target language while their attention is focused on mobilizing their grammatical knowledge in order to express meaning, and in which the intention is to convey meaning rather than to manipulate form. (p. 4).

Tasks are based on real-world language functions designed to transfer knowledge and abilities that serve learners in real-world scenarios. For instance, TBI uses activities like filling out a job application form to simulate a real-world situation. In addition, in the classroom, pedagogical tasks are sequenced to increase the complexity of a language (Long, 2015). While the task is 
implemented, students can exchange information focusing on meaning and not on patterns or structures. Language is the means to accomplish an expected outcome. The whole process of carrying out a task encourages learners to use the language without overthinking the structure of the language.

There are several features of the language that can be explored in the classroom, however, the learning mechanism to acquire them is either discovered by the students or presented by the instructor. Brandl (2008) states that "for years, the literature on foreign language teaching has been concerned with whether grammar structures and rules should be made explicit to the learner" (p. 106). Second language learners can acquire language features either in a natural way if they are exposed to comprehensible input or in a defined way if the instructor explicitly goes over the grammar instruction. In the classroom, this natural way of learning by exposure to input takes the form of implicit grammar teaching which is characterized by the absence of grammar explanations. In other words, the learner infers the patterns or rules on his own just by exposure and interaction with the input. According to Brandl (2008), in implicit grammar teaching, learners can acquire language if they receive enough input from the teacher. The different hypotheses that learners make about the language lead them to correct as well as incorrect assumptions.

On the other hand, explicit grammar instruction is a form of instruction in which grammar rules are defined, explained and exemplified by the teacher (Brandl, 2008). In presenting grammar explicitly, learners can monitor their language use, which allows them to notice connections between forms and functions and ultimately, helps them compare the input with their own output (Rebuschat, 2015). Both explicit and implicit instruction have been compared and analyzed in different research studies and many claimed that formal grammar instruction (explicit instruction) appears to provide more benefits (Brandl, 2008). Some learners in the foreign language context 
are more accustomed to form oriented than to meaning oriented instruction, which renders explicit teaching more successful in drawing learner's attention to target forms (Rebuschat, 2015). However, since some target forms are complicated, explicit instruction needs to find its way in the classroom without sacrificing time for interaction.

Ritchhart et al. (2011) claimed that educators must move from rote memorization of knowledge and facts, what he calls 'surface learning', "towards active and constructive processes or deep learning" (p. 7). This mindset requires rethinking the role of the learner and the instructor in the classroom. Approaches today not only aim to promote active and constructive processes but recognize that humans are inherently social. Hummel (2014) asserts that CLT gives an opportunity to use the target language in a creative way. Also, CLT focuses on interactions between humans and communities that facilitate learners recognizing and experiencing the language. However, social practices have also evolved, and technology is part of these new social practices.

The use of computers in the language classroom has grown almost at the same pace that language teaching. Akcaoglu (2008) describes that Computer-Assisted Language Learning (CALL) has evolved over three different waves of technological innovations and pedagogical practices. The first wave (Behavioral CALL) replaced grammar worksheets with computer-based worksheets, the second wave (Communicative CALL) designed software for communication, and the present wave, (Integrative CALL) uses software that aims at teaching language skills. In integrative CALL, media helps to create real-life situations, language skills can be joint into activities, learning environments foster autonomy and most importantly it facilitates a principle focus on the content (Akaoglu, 2008). The technological innovations in CALL have highlighted the experiential learning, motivation, authentic material, interaction, and individualization in the 
learning process. However, CALL has been criticized by the absence of rubrics, and concrete guidelines (Lee, 2000).

The use of technology in language learning to facilitate education is not new. In the foreign language classroom, educators have incorporated technology to engage students in the target language and to cover descriptive content in the foreign language. However, the use and integration of technology are different concepts as Gorder (2008) explains in his study where he assessed the teachers' perceptions of technology integration in the classroom. The author's findings reveal that teachers used technology for professional productivity and to facilitate the delivery of instruction, but they did not integrate technology into teaching and learning. Some of the results showed that teachers used technology mainly for their productivity such as project presentations of any kind, search for general content on the internet, interact with management software, etc. However, few used electronic portfolios, video conferencing, web-based collaboration programs, blogs, weblogs, and podcasts, which could help with students' learning. In his conclusions, Gorder (2008) stresses the importance of integrating technological tools in a way that benefits not only teaching practices but most importantly students' learning.

Prensky (2014) distinguishes between two kinds of students, the Digital Natives who are students who have grown with technology and Digital Immigrants who are students who were not born with technology but have adopted it at some point in their lives. One aspect about learners today is that they "think and process information differently from their predecessors" (Prensky, 2014, p. 2). Today's learners receive information fast. They multitask, they prefer graphics before the text, they function best when they networked and they thrive on instant gratification and frequent rewards (Prensky, 2014). It is, therefore, important to consider this way of processing information when teaching practices are evaluated. The flipped model manages to integrate 
"outdated practices" into more updated teaching processes. For language classes, the flipped model seems to leverage technology to increase interaction with students (Bergmann and Sams, 2012). According to Prensky (2014), teachers must adapt materials to the language of Digital Natives. In other words, we need to adapt our teaching to the technological tools that students use.

Technology has gained ground in today's classroom by moving out the content of feedback, homework, exams, and more, from the classroom to online platforms. Nonetheless, parts of the class as lecture or instruction remain part of the face to face activities. Basal (2015) uses the term "humanware" to explain that the key to using technology in language teaching successfully relies on the teacher's capacity to plan, design, and implement practical activities. The flipped model claims that by moving the lecture content into videos and out of the classroom setting, the teacher can make the most of in-class time (Bergmann \& Sams, 2012).

The flipped classroom model seems to share some foundations of CALL, as it uses software to transfer information out the classroom setting and focuses on individual learning. However, CALL uses virtual environments only, and the flipped model operates in virtual and in-class environments. At first glance, the flipped model seems to be flexible to adapt to different teaching methods, as it only moves whatever is considered lecture content to a more individual learning space. However, CLT approaches do not encourage lecture content in class but still require some emphasis on grammar instruction; Hummel (2014) explains that teachers should give more importance to the interactive and conversational meaning-based language in the classroom than on the grammar rules. To appreciate the possible applications of the flipped model in language learning, it is important to first grasp its history and contribution to other subjects. 


\section{Flipped classroom history}

Jonathan Bergmann and Aaron Sams from Woodland Park High School are very well known for their contribution to the flipped classroom. Although they recognize this is not something new, they were the pioneers in seeing the potential of this model. Bergmann and Sams (2012) noticed that in their chemistry classes, students kept reporting that classroom time was not enough to go over all new concepts and practice them. The time spent in the classroom explaining new content limited the amount of practice students could do in the classroom. However, without explicit instruction, students could not do the practice exercises. After reflecting on these difficulties, Bergmann and Sams emphasized that taking notes in class, doing the assignments, and catching up with lessons were the main problematic issues in their classes.

Due to poor results from assignments and motivated by a technology magazine, the authors decided to record PowerPoint slides explaining topics of the class and distributed them online on YouTube. They assigned those videos as homework to reach every student and use the time in class to help students with concepts they did not understand. The results of inverting the classroom lecture and bringing homework to class was a total success. Students watched videos to review, to practice, and to catch up. Since the videos were on YouTube and available to others, teachers from all over the globe were able to use these videos for their purposes. Eventually, other teachers at Woodland Park High School started using this flipped learning model in different subjects and they also found positive effects on the teaching and learning process in their classrooms.

Bergmann and Sams (2012) divide the process of flipping your classroom into two. The first part consists of transferring lecture content into videos made by educators so that students can go at their own pace; they can stop or rewind the videos and take notes; this is done outside the classroom setting. In the second part, students must complete homework, projects, guided and 
independent practice, and high order of thinking activities in general. This means "that which is traditionally done in class is now done at home, and that which is traditionally done as homework is now completed in class" (Bergmann \& Sams, 2012, p. 13). This inversion or flipped model resulted in a different setting for the classroom as seen in Table 1.

\begin{tabular}{|c|c|c|c|}
\hline \multicolumn{2}{|l|}{ Traditional classroom } & \multicolumn{2}{|l|}{ Flipped classroom } \\
\hline Activity & Time & Activity & Time \\
\hline Warm-up activity & $5 \mathrm{~min}$. & Warm-up activity & $5 \mathrm{~min}$. \\
\hline Go over previous night's homework & 20 min. & Q\&A time on video & $10 \mathrm{~min}$. \\
\hline Lecture new content & $30-45$ min. & & \\
\hline $\begin{array}{l}\text { Guided and independent practice and lab } \\
\text { activity }\end{array}$ & 20-35 min. & $\begin{array}{l}\text { Guided and independent practice and } \\
\text { lab activity. }\end{array}$ & $75 \mathrm{~min}$. \\
\hline
\end{tabular}

Table 1. Class time for traditional vs. flipped classroom by Bergmann and Sams.

While in the traditional classroom, time was mainly devoted to going over assigned homework and explaining new concepts, in the flipped classroom, time is mainly used for guided and independent practice and activities. The reason behind this time enhancement is that lecture time for new content is not part of the class because the explicit instruction is moved to the videos created by the teacher and assigned as homework prior to coming to class.

Although this model claims to encourage interaction by allowing students to complete high order of thinking activities, projects, and having a question and answer section (Q\&A) in the classroom, it also aims to tackle individual needs. Bergmann and Sams (2012) claim that "flipping the classroom establishes a framework that ensures students receive a personalized education tailored to their individual needs" (p. 6). The flipped classroom model allows students to work at an individual pace. Students who have difficulties with a topic, can repeat the content, and pause the video at any moment. For students who want to learn more content more deeply, they can explore the resources at will. The idea of individualized learning is to let students process the content of the information at their pace and to assist them if needed. In addition, the role of the teacher also changes in a flipped classroom as some of the teachers in Woodland Park High School 
mentioned "the time when the student really needs me physically present is when they get stuck and need my individual help. They do not need me there in the room with them to yak at them and give them content; they can receive content on their own" (Bergmann and Sams, 2012, p.5).

Bergmann and Sams were chemistry teachers so understandably the flipped classroom gained popularity in pure sciences as they are mainly lecture-based classes. In fact, some may say that lecture content is complicated in these subjects and therefore, placing content in a video tutorial that students can watch at their own pace and as many times as necessary may be beneficial. Based on the positive results obtained in STEM subjects, this model was recommended for all other subjects including languages. However, although language classrooms do not typically lend themselves to extensive lectures (Berret, 2012), we still explicitly lecture on the main language skills: reading, writing, speaking, and listening (Al-Harbi et al, 2016).

For Bergmann and Sams (2012), the dynamic of making videos without the audience (students) is somewhat artificial, so they recommend ways to create videos and make them fun. For example, the use of animations, simulations, or online multimedia modules are great ideas to process information not only effectively but innovatively. The authors encourage teachers to explore technology to flip their classrooms such as screen-casting software, pen annotation, interactive whiteboards, microphones, webcams, recording software, and video cameras. Taking into consideration that "homework" is pivotal in the flipped classrooms, there are activities to motivate students to work with the content before coming to class and different ways to present that content. The flipped classroom relies on the pre-class work; therefore, students need to respond to open-ended questions, attempt to solve problems, prepare questions about the instructional material, among others. 


\section{Research on the flipped classroom}

Research has assessed the impact of the flipped model in their lecture content-based classes on diverse subjects, for instance, pharmacotherapy, programing, the pathophysiology of shock, and mathematics, just to mention some (e.g., Kugler et al. 2019; Yildiz, 2018; Rehman et al. 2020; Umam et al. 2019). These studies have observed that the flipped model can be effective in enhancing student's performance and motivation. However, math teachers have emphasized the challenges during the application of the model regarding technical issues, editing and recording skills, and time constraints (Umam et al., 2019). These challenges had to do with the planning stage, but the application of the model keeps showing improvements in terms of independent learning, and in-class activities' engagement.

Changing from a traditional teaching model to a new one may come with some challenges, as evidenced by research that has sought to compare traditional teaching with flipped learning models. Strayer (2007) compared a traditional classroom with a flipped classroom at an introductory statistics class at the university level. In order to assess students' perceptions and experiences, Strayer audiotaped classroom sessions, used individual and focus-group interviews, gathered field notes from research team members, and completed reflective journals. His findings showed that initially students were less satisfied with the flipped classroom than with the regular class but gradually they became more open to cooperative learning and innovative teaching methods during the course. Strayer reasons that lack of enthusiasm to this innovative way of teaching may be that in introductory classes students do not have a deep interest in the subject and they can be frustrated when they find a new teaching model. Therefore, a transition between the traditional and the flipped classroom is suggested. 
Researches have scratched the surface of an evaluation of the flipped model, but most of them focus on the students' perception of this new way of teaching. Hussain et al. (2015) used the flipped model to prepare future teachers in pedagogical skills. His study aimed to investigate the effects of the flipped model on this subject. Students (prospective teachers) were instructed in pedagogical skills with ready-made videos, audios, reading material, pictures, diagrams, and PowerPoint presentations. In class, students had to implement the same information. Using a questionnaire, the researcher measured students' perceptions before and after the flipped learning approach regarding four pedagogical skills: planning for instruction, presentation skills, classroom management skills, and classroom assessment skills. The results of the study showed that the flipped model provides students with an opportunity to plan regularly for the class as they had to implement the same information in the class. The regular opportunity to present in the workshops had a positive impact on the presentation skills. The students also perceived that classroom management skills need to be used in organizing the flipped learning approach. The preinstructional discussion, quizzes, and other related activities contributed to the positive results in the classroom assessment skills. The author highlighted the importance of making practical handson activities to have positive and significant influence.

\section{Research on the flipped foreign language classroom}

Studies have compared traditional teaching contexts with flipped classrooms and their impact on language performance (e.g., Al-Harbi et al. 2016; Namhee, 2015; Teo \& Sathappan, 2018, to name a few). Studies used pre-tests and post-tests to measure students' grammatical and vocabulary knowledge as well as questionnaires to collect student's perceptions. Although most of these studies agree that the flipped classes had better results than the traditional classes in terms of performance (Namhee, 2015; Teo \& Sathappan, 2018); Al-Harbi (2016) did not find a statistical 
difference between the two groups. The author claims that there is no statistical conclusion that the flipped model positively affected the students' proficiency. In general, students' opinions and attitudes about the flipped classroom are positive (e.g., Al-Harbi et al. 2016; Namhee, 2015; Teo \& Sathappan, 2018, to name a few). Many students' comments highlight positive aspects such as more time for in-class activities and interaction.

Oki (2016) also examined the effects of a flipped model in a content-based instruction ESL context in Hawaii and found that students' academic performance was not impacted by the flipped classroom. In this action research study, students' perceptions of the flipped model as well as course grades were used to examine the impact of flipped learning. Like other studies, these ESL students seemed to enjoy their flipped classroom because they perceived that class-time was used more efficiently and that the teacher's role to facilitate learning. However, the post-course questionnaires and the academic performance did not reveal statistical difference; in fact, the author claims that "students will perform similarly in either flipped or traditional contexts." (Oki, 2016, p. 69).

Research has also revealed the importance of homework completion and the teacher's role in flipped learning. In Kang's (2015) study, twenty-four ESL university students were introduced to the flipped learning approach to make a comparison with the regular classroom. These students were asked to complete two types of pre-preparation assignments: grammar videos and worksheets during a regular ESL class. In order to collect information about the efficiency in terms of grammar and vocabulary knowledge, the teacher used pre and post-tests. Questionnaires and interviews were used to collect the students' perceptions over the model. A comparison of the results of the flipped model and the regular classroom in terms of efficiency did not reveal significant differences. However, the flipped classroom produced statically significant changes in both 
vocabulary and grammar knowledge. The students perceived that the flipped classroom maximized face time, interaction, and achievement of learning goals. Nonetheless, they also mentioned that not completing the assigned homework prior to class made them uncomfortable because they could not participate in class resulting in a reduction of their motivation and connection with their classmates. The students' perception also highlighted the instructor's role as a facilitator to boost the students' learning. In general, the perceptions of the flipped classroom were highly positive in satisfaction, helpfulness, the value of in-class activities, and the instructor's role.

The vital role of the teacher in the flipped classroom goes beyond the classroom, as teachers need to deal with issues related to workload, technical issues, and student's autonomy (e.g., Basal, 2015; Han, 2015). Basal (2015) looked at foreign language teachers' perceptions towards the use of the flipped classroom. This study counted with 47 prospective ESL teachers (students) in advance reading and writing classes, the study had two phases. The preliminary phase was used to examine and resolve possible problems with the implementation of the flipped model. For example, the author recognized problems with videos' completion, length of the videos, and late delivery of the videos. In order to solve these problems, it was decided to include secret words in the videos to make sure that students watched them, limit the length of the videos to 15 minutes, and post the videos four days prior to the class. helped to encounter problems after applying the flipped model that were eliminated in the second phase. The second phase was used to learn the opinions of the participants through open-ended questions in a written questionnaire. Students commented on the benefits of learning at one's own pace, advancing student preparation, overcoming the limitation of class time, and increasing participation. Basal (2015) stressed the value of the teacher s "other than technical issues, the success of a flipped learning model depends on the teacher applying it" (p. 34). 
Students' autonomy is also key to the success of this model (e.g., Homma, 2015; Han, 2015; Webb \& Evelyn, 2016). Homma, (2015) defines autonomy as "learning with opportunities for home practice to be able to exercise control over learning" (p. 254). To investigate how different types of learners react to flipped learning, Homma (2015) carried out a study where the flipped model was gradually implemented in two ESL classes with two different sets of students. One class was an ESL course for freshman university students and the other was an ESL conversational class for professionals. A partially flipped classroom was applied throughout the first five weeks of the semester to use the videos and the online material. By the sixth week, students kept watching video tutorials at home, but they were also given full access to other online material for practice. Students' perceptions of the flipped model were collected by means of an oral interview and a survey. Although all students considered that the course material helped them improve oral and written performance in class, they gradually gave more relevance to interactive and digital skill practice. The professional language learners perceived that being able to use the course materials at will allowed them to evaluate effective steps to their target goals. Although both groups have access to the same material the freshmen group did not know how to choose from the various resources offered to practice and learn, so it was difficult for them to make independent choices of learning materials. Homma (2015) concluded that being familiarized with a learning style can help students to make informed choices, become independent, and responsible leading to autonomy in language learning.

Research on the flipped model in Spanish as a foreign language class is very limited, to the author's knowledge. Moransky and Kim (2016) compared the learning of complex Spanish grammatical structures in flipped or inverted classrooms (IC) and in-class presentational classes (CP). An attitudinal inventory scale rating was used so that students could rate their assignments 
in terms of comfort, enjoyment, and confidence with the material. To assess L2 knowledge a grammatical judgment test, a usage description task, and a chapter test were used. The results showed that students in the IC scored higher in the grammatical judgment test, although no statistically considerable difference was found for both $\mathrm{IC}$ and $\mathrm{CP}$ in the usage description task or in the chapter test. The results from the attitudinal questionnaire showed the students' preference over the flipped model. Some of the aspects highlighted included the achievement of goals and the facilitation of deeper processing of the material. The results also showed that preparing for a lesson before class helped students to participate more in language discussions in the classroom.

In foreign language instruction, more research is needed to evaluate how flipped learning can help in the classroom and outside. Particularly three seems to be a need to investigate how flipped learning impacts language performance and acquisition. In fact, some propose not only to move grammar out of the classroom but also other language skills so classroom time can be used more effectively (Kang, 2015). Finally, although students are the beneficiaries of flipped learning, more research is needed that focuses on the role of the teacher not only in a flipped classroom but also in the process of implementing flipped learning. Action research offers teachers to be researchers in their own classroom and therefore, this research methodology seems well suited to evaluate the implementation of flipped learning in a cyclical way.

\section{Action research}

Mills (2011) explains that the origins of action research (AR) have been documented but also debated. Kurt Lewin was accredited with the term action research in 1934 (Mills, 2011). This type of research was described at that moment as a process of reflecting upon an issue, discussing the solution, planning, and acting. At an early stage, AR was used in the United Kingdom to reform the curriculum and to professionalize educators. Mills states that the primary effort of AR was to 
enhance the students' lives to learn about the craft of teaching. The role of the teacher is key, as AR focuses on teachers that examine issues that occur in their immediate context.

The goal of traditional educational research is to explain, predict, and control educational phenomena. According to Mills (2011), AR provides teachers the opportunity of continually observing their students, collecting data, and changing practices to improve student learning and the classroom environment. One of the aims of AR is to increase certainty by creating predictability within the classroom. In an AR study, quantitative and qualitative methods are often combined. Quantitative research focuses on the collection and analysis of numerical data. Mills (2011) states that "quantitative research method is the philosophical belief or assumption that we inhabit a relatively stable, uniform, and a coherent world that we can measure, understand and generalized about" (p. 4). On the other hand, qualitative research uses narratives to collect data and understand the way things are, and the reasons behind the study for the participants. A combination of quantitative and qualitative methods leads to a more in-depth understanding of the phenomenon.

The process to apply AR follows four simple but precise steps: to identify an area to focus, to collect data, to analyze and interpret data, and to develop an action plan. McNiff and Whitehead (2011) explain the process in a simplified way.

Take stock of what is going on; identify a concern; think of a possible way forward; try it out; monitor the action by gathering data to show what is happening; evaluate progress by establishing procedures for making judgments about what is happening; test the validity of claims to knowledge; modify practice in light of the evaluation. (p.8)

The steps need to be repeated in cycles, as seen in figure 1. This cyclical research process permits a reflective stance; or the willingness to examine daily teaching routines in order to 
improve or enhance them. Additionally, the process permits to make informed and educated decisions to modify, change, eliminate things in the class, and learn from experience (Mills, 2011).

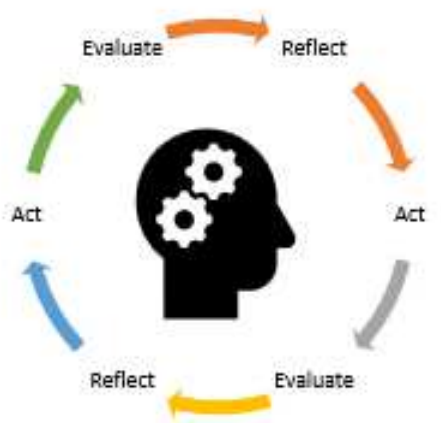

Figure 1. Systematic inquiry based on ongoing reflection (Hendricks, 2006, p. 18)

The qualitative data collection techniques for AR include tools for capturing everyday life as observations, visual recordings, interviews, and oral history or narratives stories. In AR, recording and observing as much as you can is highly recommended to get that deeper understanding of the phenomenon being studied. Researchers should do persistent observation, use data collection techniques, and not rely only on one source of data (Mills, 2011). Triangulation of qualitative and quantitative data is very important because both can "build on the synergy and strength that exists between qualitative and quantitative research methods" (p. 93).

To conclude this review of the literature, we have seen that the flipped model has offered great results for different disciplines, including foreign languages. Despite the fact that in foreign language classes, lectures on content tend to be limited in length and scope, time using the TL is needed to learn and therefore, teachers are always looking for ways to increase TL interaction in the classroom. Flipped learning can help in offering that extra time that is needed to increase the number of opportunities to practice the TL in the classroom. Much of the literature in flipped learning in foreign language instruction has focused on comparing traditional classrooms with flipped classrooms and observing the effects of flipped learning in students' performance and the 
students' opinions. The role of the teacher in implementing the flipped model also deserves attention. The present study was designed to qualitative and quantitative evaluate the teacher's perception over the implementation of the flipped model in a Spanish as a foreign language class. In this action research, I plan to answer the following questions.

1. What are the students' perceptions and attitudes toward flipped learning?

2. How does flipped learning impact teacher's philosophy of teaching and teaching practices? 


\section{CHAPTER III: METHODOLOGY}

\section{Participants}

The data for this study came from a second language teacher, and his twenty-one students ages 18 to 20 enrolled in a basic Spanish class at Illinois State University in Normal - Illinois, United States. The teacher-researcher (TR) that participated in this study was in the first semester of the second year of the Master's program in Languages, Literatures, and Cultures. The language learning group consisted of students who had already taken the first semester of the Spanish language (i.e., SPA 111) or had taken two years of high school Spanish.

\section{Teaching context}

Many students at this university need two semesters of a foreign language to fulfill an academic language requirement for their majors. The language course that the TR taught was the second semester of Spanish (i.e. SPA 112). Each class session met four days a week for fiftyminute classes for fifteen weeks for a total of sixty hours per term. According to the course description, the dynamics of a regular class consist of pre and post-class preparation. In other words, before coming to class, students must read or watch tutorials that present the vocabulary and grammar to be practiced in class the following day. In class, assigned content for the day is reviewed and put into practice extensively through activities with their peers. This means that instructors usually start classes offering brief grammatical or vocabulary explanations to review the content that students had supposedly viewed in the online grammar tutorials that accompany the textbook. After these in-class brief grammar or vocabulary presentations, the instructor moves to practice exercises, many of which come from the textbook. These practice exercises are communicative in nature where often students work in pairs to explore and exchange personal meaning. The learning goals for this class are to develop speaking, reading, listening writing, and 
cultural awareness to have knowledge of the basics of Spanish. Arriba, comunicacion y cultura (Zayas-Bazán, Bacon, and Nibert, 2019) is the book used for this class. This textbook comes along with an interactive platform called MySpanishLab (MSL) with access to the e-book, practice exercises, and language learning resources. All homework for this class is done through the online platform and represents $45 \%$ of the course grade.

\section{Data collection instruments and procedures}

This action research study was conducted using both quantitative and qualitative methods such as questionaries and field journals to collect data. These methods aimed to gain a broader spectrum of results on the impact of a flipped teaching model on teacher's and students' attitudes and practices. By using more than one method, the TR made sure to obtain more accurate results, as well as gain credibility by not relying on one source of data (Mills, 2011).

\section{TR's survey}

To obtain both numeric and non-numerical data, the TR adapted a twenty questions-survey used in Walton's (2019) study that the TR completed after the lesson had been imparted (see Appendix A for the survey). The survey has nineteen questions that focused on planing, lesson goals, students' participation, materials, and tools. The type of questions in the survey included statements to agree or disagree. For the planning section, five statements aim to assess the process, the preparation of instructional materials, the pace of the lesson, and the degree of difficulty to plan the lesson. For the lesson's goals, four statements assess the clarity and appropriateness of the lesson objectives, the use of class time, and the accomplishment of the objectives. For the student participation, the first two statements focus on students' engagement and comfort with the activities, and an open-ended question aims at categorizing class activities based on students' participation and engagement. There are five statements in the materials section that intend to 
assess relevance, appropriateness considering students' interests, level and age, completion of the activities, participation, and the usefulness of the material for future uses. The final section assesses the technological tools and their importance to the accomplishment of objectives, and adaptability in the class. Besides completing the survey after each lesson, the TR also commented on the implementation of the lesson using written or orally recorded journal notes. The TR completed the field journals for twelve lessons before and during the implementation of this research.

\section{Students' survey}

To examine students' practices, the TR asked students to complete a written survey. The students' survey was anonymous to gather honest opinions about the lesson. This tool aimed to collect numeric data about the students' homework completion, agreement or disagreement of statements, and perceptions of learning and teaching(see survey in Appendix B). Also, there was a section for every question where the student could leave additional comments. The students completed the questionaries only when the flipped classroom model was applied during the last five minutes of the class.

\section{Data analysis}

The TR followed a detailed teaching schedule given by the language supervisor that explains the topics and textbook pages to cover every week of the term. All instructors in SPA 112 follow the same schedule. As indicated, students are supposed to complete homework assignments before coming to class on the virtual platform. MSL offers help through video tutorials in English and the electronic book that redirects the student to the pages that cover the grammar topic. Students are required to watch the video tutorials that come with the textbook, and complete one or two online exercises called (Comprendes) to check their understanding of the material. A sample of one of the Comprendes exercises and the learning tools available to students appear in Figure 
2. Students are told to click on the top section of the exercise to access the video tutorial and the textbook pages. All video tutorials are animated and in English and last approximately two minutes each.

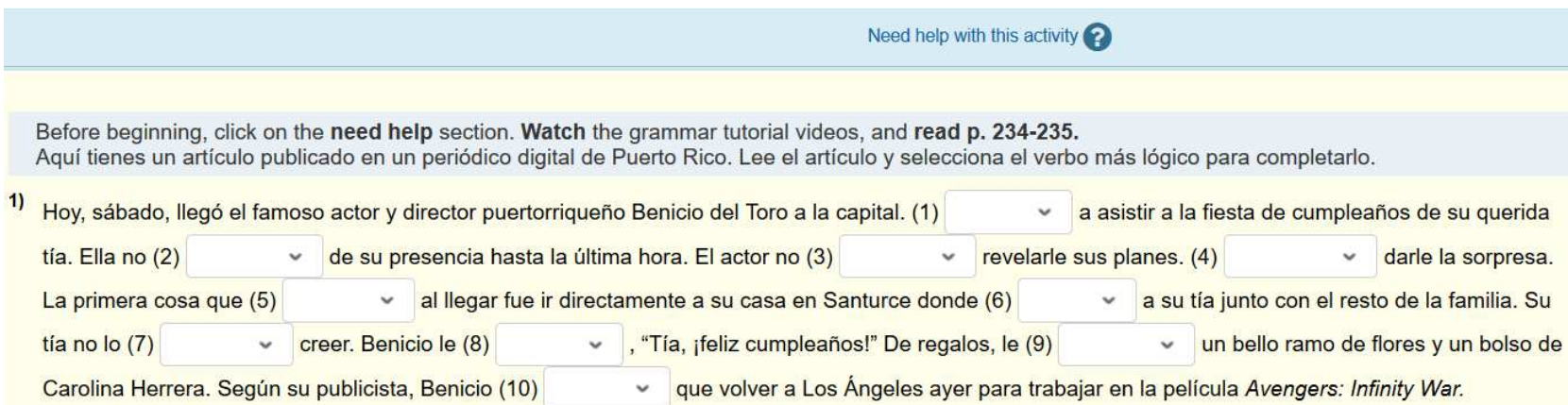

Figure 2. Sample of MSL's activity and tools to help.

For this study, it was decided that the flipped classroom would take place in days where the focus was on grammatical structures. Often, explicit grammar instructions take time in the classroom, and therefore, it was decided it would make sense to explore the impact of imparting grammar instructions outside the classroom. As mentioned, the current class selected for this study engages in what could also be considered a semi-flippled model since students are asked to watch grammar/vocabulary tutorials prior to coming to class but the teacher also offers explicit instruction on grammar and vocabulary. It is important to notice that before implementing the flipped lessons, students were familiar with the online platform and all the resources it offers. Therefore, it was assumed that students' lack of technological knowledge was not a variable to consider in this research.

The implementation of the flipped model was decided for several grammar lessons from weeks seventh to eleventh. The selected lessons are highlighted in the scheduled as seen in Table 2. The selection of these four lessons was made based on the amount of time between lessons so that the TR could examine the results from the surveys and make necessary changes for the next 
lesson. For this study and the presentation of results, we will refer to each lesson by the grammar content it represents. Therefore, the targetted flipped lessons are Lesson 1: Irregular Preterite Tense (Week 7), Lesson 2: Direct and Indirect Object Pronouns (Week 8), Lesson 3: Imperfect Tense (Week 9 ), and Lesson 4: Impersonal "se" (Week 11).

\begin{tabular}{|l|l|l|l|l|}
\hline Week & Monday & Tuesday & Wednesday & Thursday \\
\hline Week 7 & $\begin{array}{l}\text { Vocabulary content } \\
\text { Pero sino que }\end{array}$ & $\begin{array}{l}\text { vocabulary content } \\
\text { Acts. deportivas }\end{array}$ & $\begin{array}{l}\text { Grammar content } \\
\text { Preterito irregular }\end{array}$ & $\begin{array}{l}\text { Grammar content } \\
\text { Preterito irregular }\end{array}$ \\
\hline Week 8 & $\begin{array}{l}\text { Grammar content } \\
\text { OD/OI }\end{array}$ & $\begin{array}{l}\text { Practice } \\
\text { OD/OI }\end{array}$ & Cultural content & Cultural project \\
\hline Week 9 & $\begin{array}{l}\text { Review before } \\
\text { online exam II }\end{array}$ & $\begin{array}{l}\text { Vocabulary content } \\
\text { De compras }\end{array}$ & $\begin{array}{l}\text { Grammar content } \\
\text { El imperfecto }\end{array}$ & $\begin{array}{l}\text { More practice } \\
\text { El imperfecto }\end{array}$ \\
\hline Week 10 & $\begin{array}{l}\text { Vocabulary content } \\
\text { Numeros ordinales }\end{array}$ & $\begin{array}{l}\text { Cultural content } \\
\text { Perfiles Peru }\end{array}$ & $\begin{array}{l}\text { Vocabulary content } \\
\text { Tiendas }\end{array}$ & $\begin{array}{l}\text { Grammar review } \\
\text { Preterito/imperfecto }\end{array}$ \\
\hline Week 11 & $\begin{array}{l}\text { More practice } \\
\text { Preterito/imperfecto }\end{array}$ & $\begin{array}{l}\text { More practice II } \\
\text { Preterito/imperfecto }\end{array}$ & $\begin{array}{l}\text { Grammar content } \\
\text { El se impersonal }\end{array}$ & $\begin{array}{l}\text { More practice } \\
\text { El se impersonal }\end{array}$ \\
\hline
\end{tabular}

Table 2. The four lessons selected to implement the flipped model

During the implementation of the four lessons, explicit instruction on grammar topics was exclusively virtual. In these classes, students watched videos online and completed the Comprendes or handouts prior to coming to class. In class, the intended plan was to start the lesson with a question and answer question and answer session in English, and then, move on practice exercises like guided or independent practice to work with the new content during the remaining time of the class. The results from the TR survey, his field notes, and the students' responses from the surveys informed the TR about necessary adjustments for the next flipped lesson. The next chapter shows the results obtained from TR and students' surveys and the changes made by the TR for each flipped lesson. 


\section{CHAPTER IV: FINDINGS AND INTERPRETATION}

The TR completed the surveys and collected field notes after the four flipped lessons but also after eight regular lessons to examine possible differences between regular and flipped lessons. A comparison of the results from the TR surveys within the four flipped lessons did not show notable differences. However, when comparing the results from the TR surveys between the regular and the flipped lessons some interesting facts were revealed, as shown in Figure 3. After experiencing the flipped model and comparing it with the regular classroom setting, two aspects stood out: goals and participation. For instance, the teacher's journals included comments about the way the TR perceived students' participation in class. The results stated that students participated slightly more in the flipped classroom than in the regular classroom setting as there were some activities designed for this purpose. From these comments the TR suggests that the flipped model encouraged students to talk about the content from the videos in the Q\&A session, which increased the students talking time perceived as participation. Also, the accomplishment of the objectives in the flipped classroom model is considerably more pronounced than in the regular classroom. One possible explanation could be that the TR did not spend time explicitly explaining grammar content, and students had more time to participate in classroom activities.

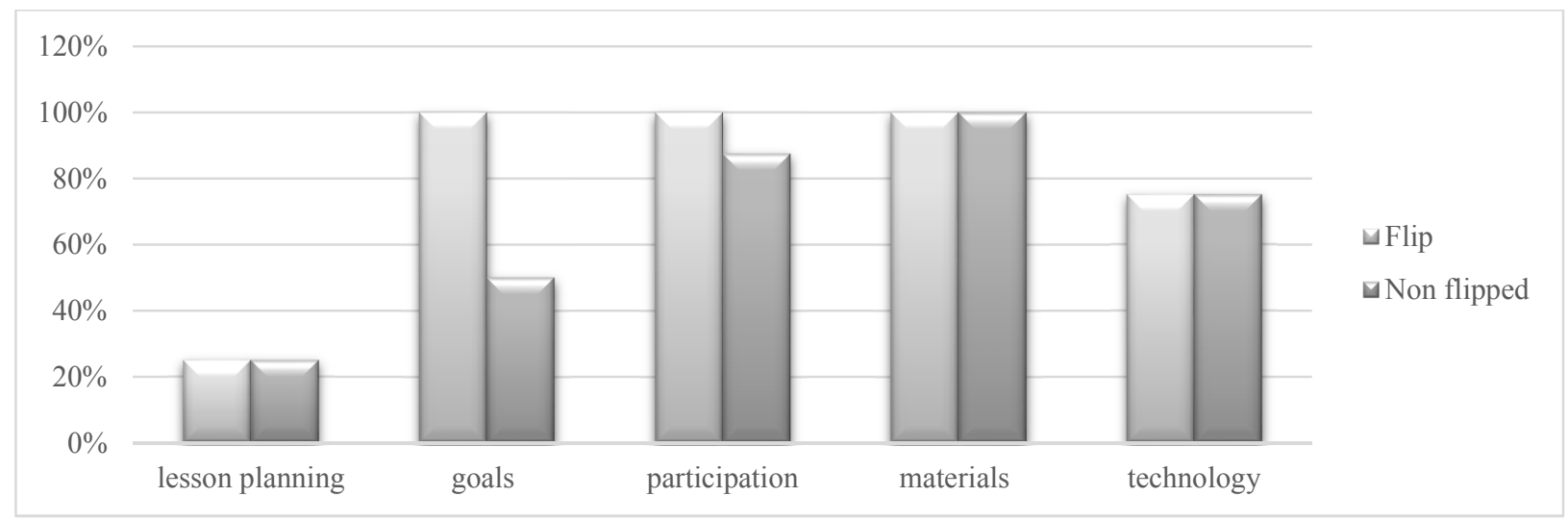

Figure 3. Teacher's perceptions of the flipped vs non-flipped classroom. 
We will now outline each lesson separately to examine the changes made between flipped lessons and the motivation behind these changes based on TR and students' perceptions as evidenced by the surveys and field notes.

\section{Lesson 1: irregular preterit tense (week 7)}

Before the lesson, the TR reminded his students to watch the grammar tutorial on MSL and complete the comprehension check activities on the online platform. Also, he informed his students by mail about the omission of direct instruction for the next class, stressing that the assigned video tutorials on MSL were dealing with the same content. In-class, the TR started by asking for the students' opinions over the video on MSL. The TR perceived that students were not able to share information about the video and he asked if they had seen the video. Most of the class did not know about the videos in MSL. This result was confirmed with the students' survey for this first flipped session, as it showed that only $11 \%$ of the class had watched the video, while the other $89 \%$ did not. Additionally, from TR's journal entries, it was clear that the students were not aware of the content for this lesson. Therefore, it was necessary to modify the lesson and instead of starting with practice exercises, the TR decided to explain the grammar content in class. Due to this decision, some of the planned activities were not able to be implemented due to time constraints. Although in the end, this lesson was not flipped as it was intended, it raised awareness about the activities in MSL and the importance of watching the video to fully implement the flipped model.

The entries on the teacher's journals highlighted aspects to consider in the planning section, and the tools used. Although the TR described that the planning stage, in general, was not difficult, the lesson plan did not contemplate that only $11 \%$ of the class was going to watch the video. Therefore, the TR acknowledged that he was able to adapt to the unexpected, but it was not part 
of the planning. The tool used to deliver instruction and to present activities in class was PowerPoint. However, the PowerPoint presentation for this first lesson did not include any slide on the grammar content, therefore, the TR had to explain the use and form of Spanish Irregular Preterit with no visual aids. TR's overall impression of this first lesson was that despite the directions given to students about what the next lesson was going to focus on and the importance of watching the grammar tutorial on MSL, one should always be prepared for the unexpected, as it happened here.

Moreover, the written and verbal comments that students made about this lesson also highlighted another issue. Students were not aware of neither the existence nor the location of the videos in the MSL platform. Some of the students' comments from the surveys included "I was not aware of the video," "where can you find that video?", "I did not receive a video." Even though students did not know where the video was, $89 \%$ were able to complete the activities online in MSL. The TR reflected upon this situation and found that many of the activities that students have to complete after watching the video tutorial are easy to figure without knowing much about the grammar concept. Students have two attempts for every activity, and after the first attempt, for each incorrect response, there is some feedback provided to help the learner to get the correct answer. However, sometimes the exercise has two choices to choose from so students can simply guess the correct answer after the first attempt. The assigned online Comprendes exercise that students had to complete for this lesson offered students two choices to choose from for all the verbs to complete a paragraph. In cases where students chose the wrong verb in the first attempt, they simply would have to choose the other option in their second attempt. According to the platform, the class average for this Comprendes exercise was $91 \%$, but $86 \%$ of submissions included two attempts. It is also relevant to mention that students get penalized $5 \%$ off the total 
score for every day that they submit the exercise late. Therefore, many students got $100 \%$ in the exercise, but because it was submitted late, the score was slightly lower. The set-up of this Comprendes exercise explains why students did not have to watch the grammar tutorial to do well. Overall, many of the online exercises that students are required to complete before class are similar to the one shown in Figure 4, which may explain why even though instructions say students need to watch the grammar tutorial and read textbook pages, many complete the exercises without any added help.

\section{Try Again}

Before beginning, click on the need help section. Watch the grammar tutorial videos, and read p. 234-235. Aquí tienes un artículo publicado en un periódico digital de Puerto Rico. Lee el artículo y selecciona el verbo más lógico para completarlo.

1) Hoy, sábado, llegó el famoso actor y director puertorriqueño Benicio del Toro a la capital. (1) $\times$ Dijos a asistir a la fiesta de cumpleaños de su querida tía. Ella no (2) $\checkmark$ supo de su presencia hasta la última hora. El actor no (3) $\times$ supo revelarle sus planes. (4) $\times$ Hizos darle la sorpresa. La primera cosa que (5) $\checkmark$ hizo al llegar fue ir directamente a su casa en Santurce donde (6) $\times$ dijo a su tía junto con el resto de la familia. Su tía no lo (7) $\times$ hizo creer. Benicio le (8) $\mathbf{x}$ trajo, "Tía, ifeliz cumpleaños!" De regalos, le (9) $\checkmark$ trajo un bello ramo de flores y un bolso de Carolina Herrera. Según su publicista, Benicio (10) × hizo que volver a Los Ángeles ayer para trabajar en la película Avengers: Infinity War.

Score: 3 out of 10 Partially Correct

Feedback: Which preterit verb logically corresponds to "he had to"?

Figure 4. Sample after the first attempt of an online exercise.

The results and reflections gathered from this first lesson influenced the decisions for the next flipped lesson. It was necessary to teach the students about the location of video tutorials on MSL, as well as their relevance in completing online exercises. Therefore, the TR decided to create a worksheet with graphic information about the location of the video tutorial for the next flipped lesson. Additionally, since the TR did not know how clear the instructions to locate the video were, he decided to create a video on YouTube and send it by e-mail. The YouTube video covered the same grammar content that the one on MSL. However, this was not an animated video, in fact, the TR appears in front of a whiteboard explaining the topic in English. Also, the TR created and sent 
by e-mail the following video-related questions that students had to answer and bring to class for the next session (Table 3)

\begin{tabular}{|c|c|}
\hline -What is the grammar topic? & -What do you use this grammar for? \\
\hline -What are the examples in the video? & -What is the grammar rule? \\
\hline Create another example & What questions do you have about the grammar? \\
\hline
\end{tabular}

Table 3. video-related questions.

\section{Lesson 2: direct and indirect object pronouns (week 8)}

The TR started the class by asking students about the video completion. Most of the students claimed that they had not watched the video on MSL, but they had watched "the teachers' video." According to the students' survey, $83 \%$ of the class watched the video, however, their comments suggest that they did not watch the video on MSL but instead, they watched the TR video tutorial. During the class, students used the grammar questions from the worksheet the TR had distributed to share what the video content was all about. This was followed by a Q\&A session that addressed questions relating to the video's grammar content (see figure 5); the student discussed the questions in groups and later discussed their answers with the class and the teacher. This section of the lesson lasted fourteen minutes and it was done in English. This Q\&A session also helped with students who admitted not having completed the assigned homework of watching the teacher's video tutorial. The lesson continued as planned and the TR was able to accomplish all the comprehension-based activities and the communicative task planned for the day. Additionally, since there were no time constraints, the TR had time to give feedback about the communicative task and to explain the location of the videos on MSL in class one more time. When the class was over, some students approached the TR and suggested that he creates videos explaining previous topics so that they could use them to study before the second chapter exam. 

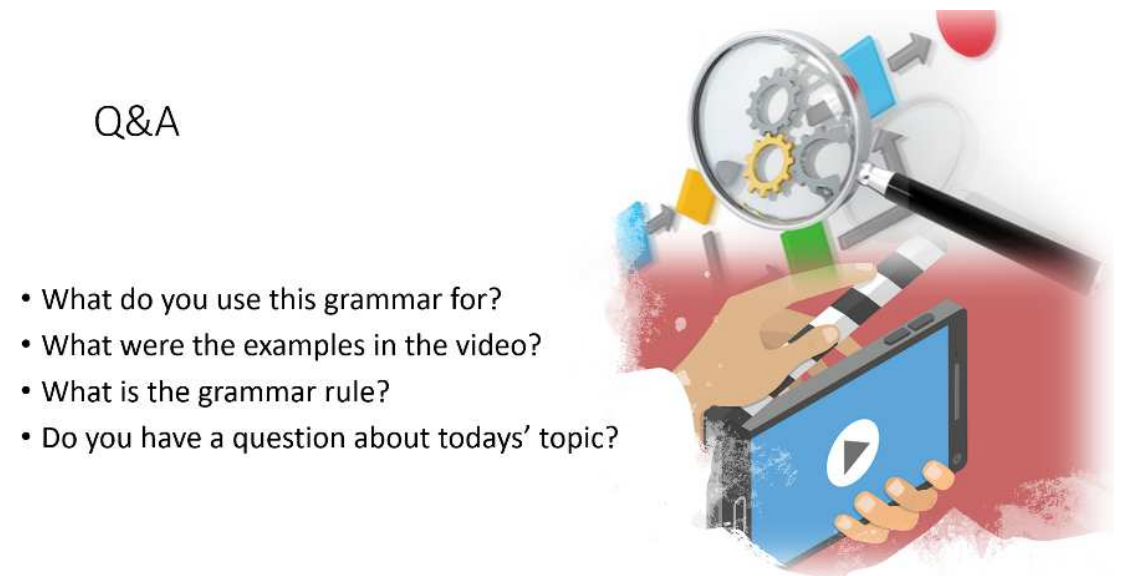

Figure 5. Q\&A slide used in class

Even though the Comprendes exercises for this lesson resembled the characteristics of the ones used for the first lesson, the results in terms of video completion improved in this lesson as $83 \%$ of students claimed they had watched the video. The Comprendes exercise for this lesson was almost identical to the one in lesson one. Students had to complete a dialogue choosing the appropriate direct or indirect object pronoun, and students were given two choices for every blank. After the first attempt students were given feedback for each incorrect answer. The average score was $94 \%$, but $95 \%$ of the students completed the exercise with two attempts. It was interesting to see that despite the fact that the video was not necessary to complete the Comprendes exercises on MSL, as it was the case with lesson $1,83 \%$ of the students watched the TR video tutorial.

The students' survey highlighted the relevance of both the video in terms of content's presentation and the activities on MSL. Based on the entries in the TR' journals and the students' comments in class, students probably had the teachers' video in mind when answering the survey. As seen in Figure 6, 94\% of the students who watched the video agreed that the presentation of new grammar content was useful. Also, $78 \%$ of students who completed the MSL activities also positively assessed the relevance of these activities. However, 11\% did not find online activities useful and said things such as: "the questions only had two options." "I do not need to watch the 
video to complete the homework." After reflecting upon the surveys and notes, the TR decided to make some changes to the third lesson. Having in mind that MSL offers animated tutorial videos included with the material for the class, the TR insisted on the use of these videos. The TR video tutorials are based on the content offered in the MSL videos, therefore, considering the content was similar, the TR wanted to once again try to encourage students to watch the video tutorials in MSL that accompany the assigned Comprendes exercise. The Comprendes exercise for the third lesson was similar to the exercises previously used for lessons one and two. Likewise, motivated by the students' suggestions over the TR video and the results in class, the TR recorded his video tutorials for previous lessons. These videos were uploaded with their corresponding activities in Google Classroom to help students prepare for the second exam.

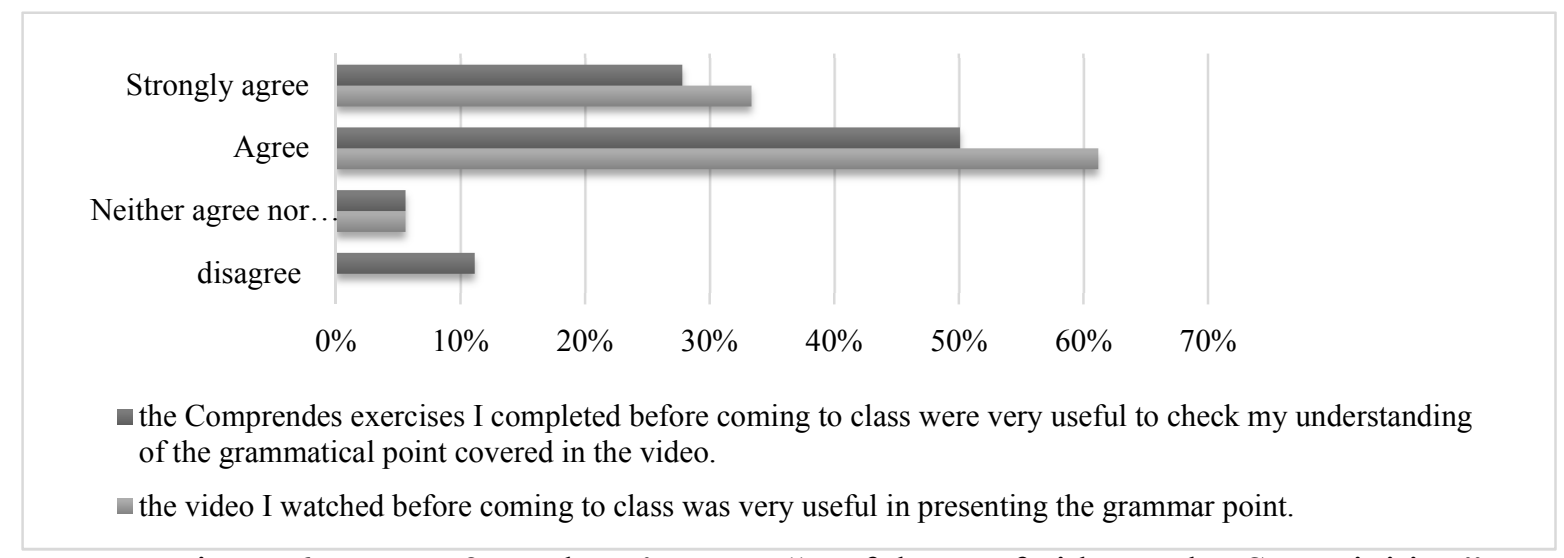

Figure 6. Lesson 2, students' survey "usefulness of video and MSL activities."

\section{Lesson 3 imperfect tense (week 9)}

Prior to this lesson, the TR reminded the class to watch the grammar tutorial on MSL and to complete the activities on the online platform. The TR started the class asking about the "day's assignment completion." Almost half of the class claimed they had watched the video on MSL. This information goes in accordance with the results from the students' survey that says that $47 \%$ of the class watched the video, and $90 \%$ completed the activities on MSL. The TR was still concerned about the fact that half of the class had not watched the video tutorial on MSL, but many 
had been able to successfully complete the assigned Comprendes exercise. In this Comprendes, students were given options to choose from to describe a store and the situations that happened in the store using the imperfect tense, however, students who chose the wrong verb in the first attempt, they simply choose the other option in their second attempt. Nevertheless, the class average was not as high as in lessons one or two (79\%). In most of the cases, students submitted the exercise twice $(90 \%)$.

Before starting the lesson, the TR had to deal with the fact that almost half of the class had not watched the video. Therefore, it was necessary to modify the lesson plan for the day. Students who had watched the video were paired with the ones who had not, and the planned Q\&A session to be led by the TR was changed to a "tutor session" so that students who had watched the video on MSL could explain the grammar content to the ones who did not watch the video. This activity took longer than expected, as the students who had watched the video had to explain the grammar content from scratch. Although this situation was not part of the planning, the TR's motivation to allow students to review and teach to each other the grammar content of the day was based on the belief that the video's completion is crucial for the reliable development of the class. These unexpected changes in the lesson resulted in added time constraints. The TR decided to sacrifice some comprehension-based activities and instead used pre-task activities so that students could accomplish the planned communicative task for the lesson.

The TR's journals from the third session highlighted aspects from the class regarding the planning stage and the assignment completion. Although the planning of the class was not difficult in general, the unexpected change of the Q\&A activity impeded the pre-established advancement of pre-tasks activities. These pre-tasks were planned to engage students in higher-order thinking to help them recognize mistakes when using the imperfect tense. Concerning student's completion 
of assigned homework, we see that although more students watched the video tutorial in MSL in this lesson (47\%) than in the first lesson $(11 \%)$, students seem to prefer video tutorials created by the teacher $(83 \%)$ like the one created for the second lesson. In the video tutorials in MSL grammar is narrated as examples are shown in different slides. There are two possible explanations of why students prefer the TR videos. First, the teacher appears in those videos talking to students so that eye-to-eye contact, even though trough a video, may contribute to students' engagement with the content. Secondly, the teacher is known to the students so the familiarity with the person in these video tutorials may also seem to contribute to students' motivation to watch the grammar videos.

Based on the students' survey results, the most common reason for not watching the video was that students forgot (Figure 7). The reason behind not watching the video on MSL could be that there is not a score incentive for it, whereas the Comprendes activities on MSL are graded. Clicking on the video tutorial in MSL cannot be traced so teachers cannot know whether students watch these videos. Students know that, which may explain why many 'claim' they forgot to watch the video. Additionally, some students commented that they were expecting an e-mail from the teacher to watch the video on MSL, as they were reminded in previous lessons. Considering the limitations that the Comprendes exercises have including the lack of direct connection between the content of the grammar tutorial in MSL and the content of the Comprendes exercise, it was decided to consider a way to join the videos and the activities so that the students would find a connection and an incentive to do the assigned activities. It was decided to eliminate the online Comprendes activities, and the corresponding video tutorial on MSL proposed for the fourth session. Instead, the TR decided to record himself for the four-lesson explaining the grammar content in English in front of a whiteboard. Additionally, he created activities to replace the ones on MSL. Students were informed about these changes in an email that contained a link to the 
YouTube video and a worksheet with questions related to the video. The questions were: "What is the first use of "se impersonal" mentioned in the video?", "What are the examples given in the video for the verbs "permitir" and "comprar"?", "What is the second use of "se impersonal" mentioned in the video?". The e-mail also informed that students had to turn in the activities in class and that these activities would be graded as a regular Comprendes exercise.

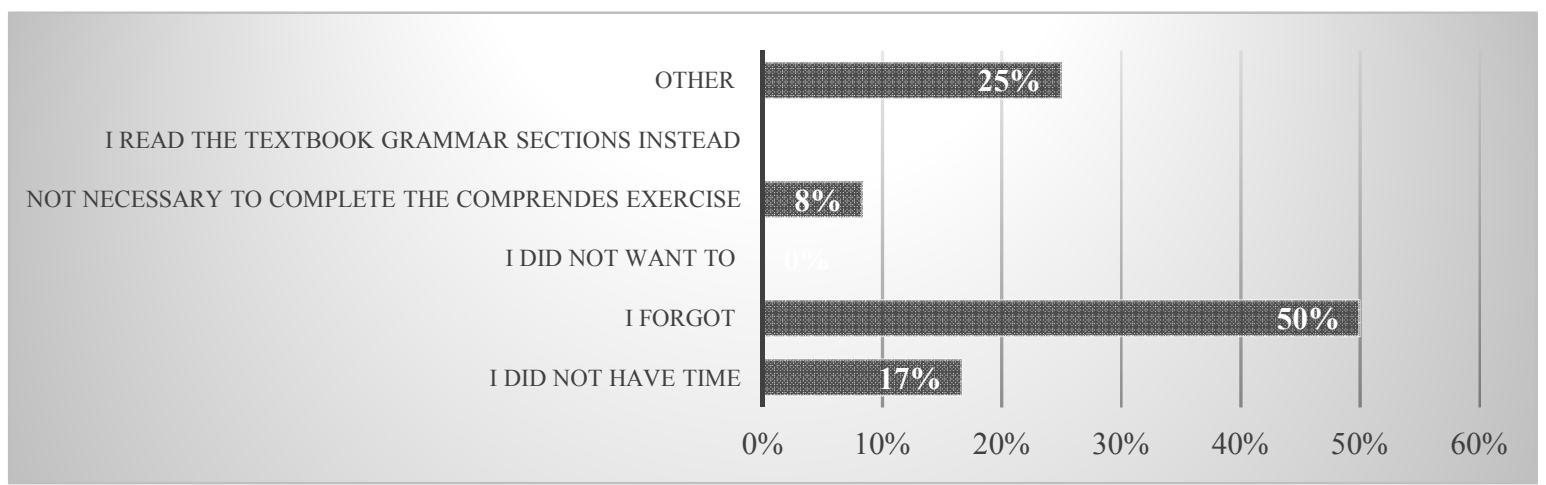

Figure 7. Session 3, Students' survey "reasons for not watching the video."

\section{Lesson 4 impersonal "se" (week 11)}

The worksheet that accompanied the TR video tutorial included questions that were chronologically designed so that students had to watch all the video to answer them one by one. The lesson started by asking the students about the worksheet completion. Almost everyone did the activities for the day including watching the video on YouTube. The students' survey agreed that the homework completion was $93 \%$ for both the video and the assigned activities in the worksheet. The class started with a Q\&A session that took five minutes, and it was done in Spanish. The questions in the worksheet were used during the whole class for different activities and it was used to structure the Q\&A discussion. At the end of the class, the students handed the worksheets and the TR graded them. Students were able to clarify misconceptions and they jumped into comprehension-based exercises to practice the topic for the day. The objectives set for this lesson were achieved satisfactorily and the TR was pleased with the students' interactions and participation as evidenced by the TR responses to the lesson's survey. This positive perception 
about class development was attributed to homework completion. According to the TR, students were willing to participate in all the activities for the lesson, and they did it in the target language because they were familiarized with the content. Another possible explanation could be, that the topic was engaging as the students had to deal with some humorous content in-class activities. For instance, as shown in Figure 8, students were instructed to state what is allowed and what is not allowed using the se impersonal structure. Since some of the signs were humorous in nature, students were highly participatory in this exercise.

\section{¿Cuáles señales son reales?}
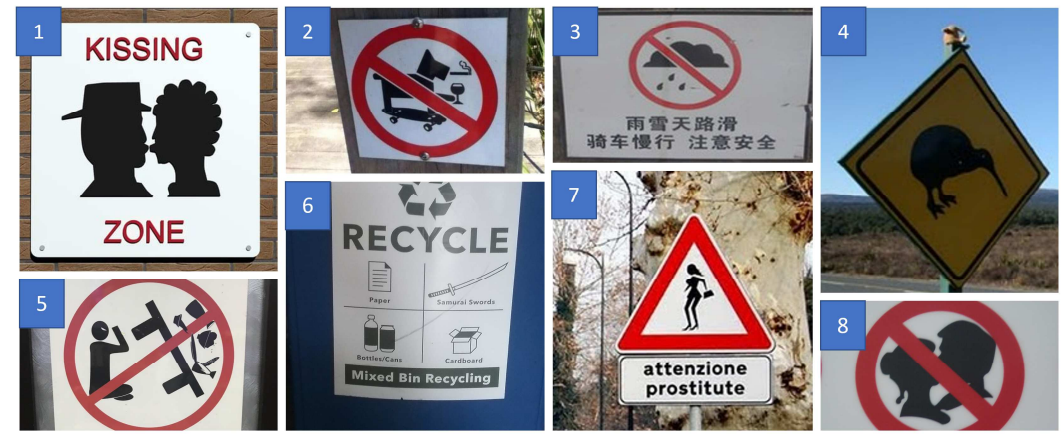

Figure 8. Sample of a humorous activity for lesson four.

Although the TR attributed the positive results of this lesson to the assignments' completion, the entries in the teacher's journal also featured the role of the lesson material. The worksheet used in this lesson not only helped the students outside of the classroom but also, helped them with in-classs activities, as in the case of the Q\&A session. Additionally, students were able to use this worksheet to support their answers to class activities and consult information when needed. Perhaps part of the motivation to participate in a class was directly proportional to the knowledge students had about the grammar content. The results from the students' survey also stressed the importance of the material. Figure 9 shows the students' agreement on statements about the video and exercises out of the classroom. As we can see, $100 \%$ of the students agreed 
that the video used before class was useful. Similarly, the students also agreed (67\%) or strongly agreed (33\%) that the exercises that accompanied the video tutorial were also useful. These results demonstrate that students perceived as positive the link between the videos and the worksheet exercise. Also, the students noticed the importance of watching the video, not only for homework completion. Some of the comments reinforced the numeric data: "videos are always nice. I can keep watching them if I do not understand it the first time."

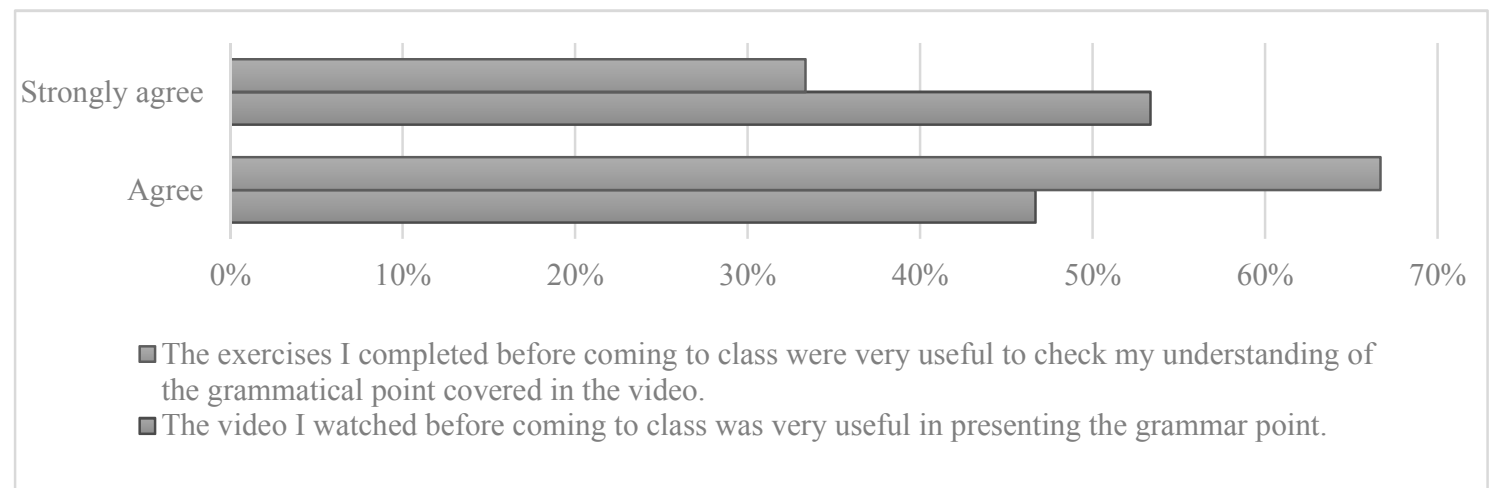

Figure 9. Session 4, students' survey "usefulness of video and worksheet activities."

We have seen the implementation of the flipped model in these four sessions and some aspects are pivotal to summarize before beginning the discussion. The fact that students knew how to complete Comprendes exercises and that they scored well did not mean that they were familiarized with the grammar tutorial videos offered by MSL. As part of the instructions for each Comprendes exercise, students are asked to watch the video tutorial and/or read textbook pages. The location of both resources is also explicitly stated in the instructions. However, many did not watch the grammar tutorials. Students preferred the non-animated video made by the teacher than the animated ones on MSL, perhaps the reason behind this tendency was the familiarity with the teacher's instruction. The relationship between the video and the activities before coming to class was crucial to have an appropriate approach to the grammar content. The fact that from sessions one to three there was not an incentive to watch the video influenced the results (see table 4). Additionally, since students did not have a second attempt for the activity completion in lesson 
four, the results were lower than in the other lessons. The Q\&A session helped not only to share information from the videos and clarify misconceptions, but it also aided students who had not watched the videos. Time gained from the flipped model was appreciated in lessons two and four where most of the students had successfully completed the activities before class. Students claimed to use the video tutorials made by the TR to study for exams and to catch up with missing classes. Overall, these four lessons showed that video tutorials need to be directly related to practice exercises. Additionally, video tutorials that feature the teacher instructing students seem to increase students' engagement and motivation.

\begin{tabular}{|c|c|c|c|c|}
\hline & Lesson 1 & Lesson 2 & Lesson 3 & Lesson 4 \\
\hline $\begin{array}{l}\text { Video } \\
\text { completion }\end{array}$ & $\begin{array}{l}\text { Students' survey } 11 \% \\
\text { Teachers' journal } \\
\text { Students were not aware of } \\
\text { the video }\end{array}$ & $\begin{array}{l}\text { Students' survey } \\
83 \% \\
\text { Teachers' journal } \\
\text { Most of the students } \\
\text { watched the video }\end{array}$ & $\begin{array}{l}\text { Students' survey } \\
47 \% \\
\text { Teachers' journal } \\
\text { Almost half of the class } \\
\text { watched the video }\end{array}$ & $\begin{array}{l}\text { Students' survey } \\
93 \% \\
\text { Teachers' journal } \\
\text { Almost everyone }\end{array}$ \\
\hline $\begin{array}{l}\text { Activity } \\
\text { completion }\end{array}$ & $\begin{array}{l}\text { Students' survey } \\
89 \% \\
\text { MSL } \\
\text { Class average } 91 \%\end{array}$ & $\begin{array}{l}\text { Students' survey } \\
89 \% \\
\text { MSL } \\
\text { Class average } 94 \%\end{array}$ & $\begin{array}{l}\text { Students' survey } \\
84 \% \\
\text { MSL } \\
\text { Class average } 91 \%\end{array}$ & $\begin{array}{l}\text { Students' survey } \\
93 \% \\
\text { Instructor graded } \\
\text { Class average } 86 \%\end{array}$ \\
\hline
\end{tabular}

Table 4. Completion of assigned activities outside the classroom. 


\section{CHAPTER V: DISCUSSION}

The present study considered four pedagogical interventions using flipped learning with a group of twenty-one Spanish as second language university learners in a beginner's class. The results obtained in this study corroborate findings in previous research about how the flipped model enhances students participation, how a grade incentive can be beneficial for groups that lack motivation and how the role of the teacher changes when this model is applied (e.g., Moranski \& Kim, 2016; Strayer, 2007; Basal, 2015). In this chapter, we discuss the teacher's overall experience with the flipped model taking into consideration the students' practices and attitudes during the implementation of the model. This study followed an action research process, therefore, as the lessons progressed, there were changes in the dynamics of the class that influenced the teacher's teaching practices as well as his philosophy of teaching. Our discussion will be organized around the study's research questions.

\section{What are the students' perceptions and attitudes toward flipped learning?}

Although the flipped pedagogical intervention was planned for four lessons, the students' failure to watch the video tutorial for lesson one forced the TR to explain the grammar focus of the lesson. Therefore, this first lesson could not be considered a flipped lesson, and consequently, data on students' attitudes and practices from that day cannot be used to address our research question. One of the major challenges in this study has been to encourage students to watch the video tutorials. Evidence of this challenge comes from the students' survey and students' comments in the class where they asserted that the video tutorials were not necessary to complete the Comprendes. The reason for these comments is that these Comprendes exercises were designed in a way that students had to choose between two choices only and there were two attempts, therefore, on the second attempt they could correct what was wrong on their first attempt. During 
the lesson two, students had the option to choose between the video tutorial assigned in MSL and the one created by the TR. The fact that students could deal with both animated and non-animated video tutorials highlighted the preference for videos where there is human instruction. Video tutorial completion for lesson three also emphasized the little interest in MSL videos as most of the students completed the Comprendes exercise but only half of them watched the videos. The video tutorial completion for lessons where the TR used his videos was higher than when videos on MSL were used. This result reinforces the suggestion of exploring and assessing different sources to present the content out of the classroom setting (Bergman \& Sams, 2012). After reflecting on these results, the TR decided to create a video and add an assignment directly related to the video for lesson four.

Lesson four made students watch a teacher-made video tutorial and complete a videorelated worksheet. For this lesson, the students mentioned that watching the video helped them to understand better the grammar and to have more opportunities to practice. Students knew that the video was necessary to complete the worksheet and that this worksheet was going to replace the Comprendes' grade. Therefore, we can indirectly infer that students value the pedagogical purpose of the flipped model. However, we cannot underestimate the grade factor as well since students know that completion of the video-related assignments (i.e. Comprendes) is linked to a course grade. For this study, Spanish 112 was an introductory course but also a requirement for some students to graduate; it is not surprising that students' motivation to complete assignments in this introductory language course is the grade. This lack of motivation and its impact on flipped learning is also shared by Strayer (2007) who had a similar result in his study with an introductory statistics class. 
All lessons were initially designed as flipped lessons. However, in two sessions the fact that many students failed to watch the video tutorials resulted in the TR having to teach grammar to ensure the successful completion of practice exercises in the lesson. However, in those lessons where the majority of students had watched the video, the TR was able to start the lesson with a Q\&A session followed by practice exercises. In these lessons, students' practices were altered. Particularly, the TR noticed changes in the students' use of the target language and their participation and engagement in class. The use of Spanish between students in the class increased when the flipped model was applied correctly in lessons two and four when the teacher did not have to explain grammar explicitly. In these lessons, the use of Spanish between the students and the TR increased during the Q\&A session. Students were eager to give examples, answer the teacher's questions, and come up with their questions using the target language. The TR also noticed that generally in class and especially during class discussions students who in the past had been reserved were now voluntarily participating. In lesson four, in particular, the fact that many students had watched the teacher-made video tutorial, completed the video-related worksheet, and had participated in the Q\&A session helped learners get a more solid understanding of the grammar, which, in turn, facilitated the completion of in-class practice exercises. A similar finding was found in Moransky and Kim's study (2016) who claimed that students' participation during class discussions and activities also increased during flipped lessons.

The objective of this study was not to measure improvements in language performance and thus, although the flipped model impacted students' use of Spanish, we do not have data regarding the quality of their language performance. However, flipped learning increased the use of Spanish in the classroom. One possible explanation could also be that the flipped classroom resulted in a more learner-centered atmosphere as in the case with the Q\&A session and thus, students had more 
opportunities to use Spanish than in a traditional classroom. A similar sentiment was shared by AlHarbi et. al., (2016) who claimed that the flipped model can ameliorate one of the most common obstacles faced in language classes, the lack of opportunities for language practice. By removing the time for content instruction in the classroom through flipped learning, students can take advantage of the time to engage in discussions, to participate, and to practice the target language.

The flipped model helped to enhance the participation and engagement of the students during the lessons where the model was applied properly. For example, the video tutorial completion encouraged students to share what they have learned with their classmates. During Q\&A sessions students were paired-up to ask each other questions, give examples, and/or ask the teacher for clarification when needed. Even when half of the class did not watch the video as in lesson three, the questions from the Q\&A sessions in the PowerPoint presentation helped students to participate and be engage. However, it is also important to point out that failure to complete assigned homework makes students feel uncomfortable (Kang, 2015). Motivation is pivotal for this model to work. Therefore, having a grade incentive to complete the video tutorial and other video-related assignments is especially useful for classes where students' motivation is low such as language classes that meet a college requirement.

\section{How does the flipped classroom impact teacher's philosophy of teaching and teaching}

\section{practices?}

In the process of implementing flipped learning, the TR reflected on the role of the teacher, teaching practices and planning, and, ultimately, the TR's teaching philosophy. One of the changes that the TR noticed in the classroom was his own role as a facilitator. During the Q\&A sessions, the TR organized discussions and kept the learner's attention on the topic. For example, in lesson three where half of the class had not watched the assigned video tutorial, the TR had to decide 
between teaching the grammar point to the entire class or deviate from the flipped model slightly by allowing students to tutor each other. The TR decided to group students so those who had watched the video tutorial would 'teach' those who had not watched the video. During these 'tutoring sessions', the TR went around the class checking on the groups' discussions and offering help. During regular Q\&A sessions in other lessons, the TR kept students on topic, encouraged interaction and participation from all students, and moderated any class discussions. As evidenced in previous research, the teacher in the flipped classroom becomes a facilitator (Kang, 2015) because he is not imparting the knowledge, but he facilitates the knowledge so that students can notice it.

Lesson four was considered the best approximation to a flipped lesson properly applied. The role of the teacher as facilitator was clear from the beginning of the class since students applied the information from the video to share and use it for the Q\&A session. In this flipped classroom, students shared ideas and discussed their thoughts of the grammar in a bidirectional way between the teacher and students which facilitated the negotiation of meaning between participants. Additionally, as the TR tried to implement flipped learning in all the lessons, the students knew about the activities to develop outside and inside the classroom. The practices of the TR asking about the material completion, the students participating in the Q\&A session, and the activities to practice are examples of the familiarity with the practices that helped in the success the TR and the students experienced in the four lesson. This result confirms that familiarity with a new model as flipped learning helps to improve the practices inside and outside the classroom (Basal, 2015).

The creation of the TR's own video tutorials was an experience that helped the TR to see the advantages and disadvantages of creating his own material. While commercially created video tutorials that come with many foreign language materials today are not an obstacle to the flipped 
model, the key relies on assigning exercises that require the understanding of the video content. Besides, the presence of the teacher in the video tutorials also seemed to be a motivating factor for students, as indicated by the TRs perception and students' comments in this study. Learners enjoy the human connection during the lecture part even though it is delivered through video. Also, it adds to the familiarity of the task since the video tutorials resemble what teachers usually do in the classroom. One of the advantages of creating your own material is that the teacher can organize the video tutorial in a way that it feels part of the lesson. In other words, the video tutorial works for the lesson instead of having the lesson adapt to the video. Additionally, the lecture content of the language classes is very narrowed and focused which permits to create very short video tutorials. These short videos can be a good way to motivate students to watch them. More advanced classes may need longer videos to explain more complex topics as syntax, phonetics, etc. One side effect of the implementation of these teacher-made video tutorials was that students requested other video tutorials to review for exams and to catch up with classes students had missed. Creating your own video-tutorials is time demanding and as Basal (2015) claims the teacher is the human factor needed to accomplish the desired outcomes for any model or technology used in education.

One misconception the TR had at the beginning of this study was that he thought students were already familiar with the content and location of resources in MSL considering, as indicated earlier, in this course students were already asked to watch video tutorials before coming to class. However, in the first lesson of this study students acknowledge they did not know the location of the animated video tutorials offered in MSL. This disconcerting discovery confirmed how students do not always know how to make decisions over learning material online (Homma, 2015). The TR immediately discovered that learners can take more advantage of the pedagogical materials they are asked to work with when they are showed the connections and benefits that they can obtain. 
This revelation impacted the TR's approach to his teaching since he had to discuss the benefits of watching the video tutorials before coming to class with students several times during the implementation of flipped learning. Students benefit from being told why certain teaching practices contribute to their learning.

After implementing the flipped model, the teacher's philosophy now contemplates the importance of enhancing the student's motivation to explore content before class. The flipped model seems to enhance participation in class due to the type of activities that the model promotes. For instance, the Q\&A session where the students need to negotiate information with classmates and the teacher. Nonetheless, the development of this type of in-class activity is related to outside activities. At the same time, the motivation to complete outside activities is connected to the benefits a student can obtain from them. This idea changed the teacher's philosophy as he understands that students motivated by the score will look for a shortcut to complete the videorelated exercises without watching the video tutorials. Therefore, the TR recognizes that students need to be motivated and guided to explore the content and see the benefits of outside activities beyond the score. 


\section{CHAPTER VI: CONCLUSIONS}

This study evaluates the process of implementing flipped learning in an introductory Spanish as a foreign language class. This action research study has revealed that flipped learning enhances student's participation and engagement since they are prepared for the class's topic. However, the failure to complete outside activities, especially watching the video-tutorials complicates the classroom pace. Also, the teacher's perceptions during this process have stressed the importance of the video tutorials and their accompanying materials. Particularly, the materials set as homework in the flipped model that need to be linked with those videos not only in terms of content, but they need to be dependent on each other.

Although several inadequacies during the first three lessons negatively impacted the implementation of the flipped model, we note that this is not an empirical study but an action research study that focuses on the process of implementing a teaching technique and examine the cyclical phases that a teacher goes through by reflecting, acting and evaluating (Hendricks, 2006). In that sense, even though the "proper" flipped lesson was only one in this study, the other three lessons contributed to the successful implementation of lesson four, which is the purpose of action research. By reflecting on what went wrong, making changes for the next lesson, and evaluating results, the TR was able to successfully use a flipped classroom that impacted on students' attitudes and practices.

Flipped learning can work if it is applied correctly both outside and inside the classroom. This study suggests that a grade incentive in assignment completion can be beneficial for groups that lack the motivation to take advantage of both the videos and the practice material outside the classroom. In class, the flipped model changes the role of the teacher as well as some dynamics of the class. This study suggests that the teacher is no longer the one who imparts the knowledge but 
the facilitator of the knowledge. The Q\&A session not only enhances participation but also benefits the grammar instruction to be less unidirectional and more bidirectional as the students are participants of the instruction.

The limitation of the study with regards to data collection to answer the research questions was the fact that there was only one true flipped lesson; lesson four. Additionally, since the decision was made for the students' survey to be anonymous to gather honest opinions about the lesson, we do not have an exact number of students who were present in all the four lessons. Finally, the students' survey included concrete questions that often had to do with the completion of assignments, instead of student's opinions and experiences with the flipped model. Therefore, students' attitudes towards flipped learning were mainly gathered from TR's perceptions and students' practices in the classroom, not from their own opinions.

This study did not contrast flipped learning with other pedagogical techniques and thus, we consider that more research is needed to address our research questions in more detail. For example, it would be interesting to compare changes in students' and teacher's perceptions and practice over two different pedagogical interventions, one of which being flipped learning. Additionally, further research on flipped learning should contrast different participants based on their interests to learn a foreign language as we have seen how in these mandatory introductory classes many students lack the discipline and the motivation to take advantage of learning material on their own. Similarly, students' changes in language performance should be investigated to evaluate the influence of the model. Finally, this study used two formats to encourage students to watch the video tutorials, however, there are different ways to make sure students watch the videos. Future teachers implementing the model should consider platforms that mix both video and 
practice materials out of class as Edpuzzle that allows the teacher to include multiple-choice questions during a video. 


\section{REFERENCES}

Akcaoglu, M. (2008). History of CALL (Computer Assisted Language Learning). Retrieved from MSU: https://msu.edu/ akcaoglu/rdp.history.html

Al-Harbi, S., \& Alshumaimeri, Y. (2016). The flipped classroom impact in grammar class on EFL Saudi secondary school students' performances and attitudes. English Language Teaching, 9(10), 60-77.

Basal, A. (2015). The implementation of a flipped classroom in foreign language teaching. Turkish Online Journal of Distance Education, 16(4), 28-37.

Bergmann, J., \& Sams, A. (2012). Flip your classroom. Alexandria, VA: Association for Supervision and Curriculum.

Bergmann, J., \& Sams, A. (2017). Flipped learning: gateway to students' engagement, International Society for Technology in Education: Eugene, Oregon and Washington, DC, 2014; 169 pp.: ISBN 978-1-56484-344-9. Center for Educational Policy Studies Journal, 7(3), 173-176.

Berret, D. (2012). How 'flipping' the classroom can improve traditional lecture. Retrieved from http://chronicle.com/article/how-flipping-the-classroom/130857/

Brandl, K. (2008). Communicative language teaching in action: Putting principles to work. Upper Saddle River, New Jersey: Prentice-Hall.

Chomsky, N. (1959). A review of B. F. Skinner's verbal behavior. Language, 35(1), 26-58.

Clark, K. (2015). The effects of the flipped model of instruction on student engagement and performance in the secondary mathematics classroom. The Journal of Educators Online, $12(1), 91-114$. 
Gaughan, J. (2014). The flipped classroom in world history. The History Teacher, 47(2), 221 244.

Gorder, L. M. (2008). A study of teacher perceptions of instructional technology integration in the classroom. The Delta Pi Epsilon Journal, 50(2), 63-76.

Han, Y. J. (2015). Succesfully flipping the ESL classroom for learner autonomy. NYS Tesol Journal, 2(1), 98-109.

Hendricks, C. (2006). Improving schools through action research: A comprehensive guide for educators. New York: Pearson.

Homma, J. E. (2015). Learner autonomy and practice in a flipped EFL classroom: Perceptions and perspectives in new digital environments. Chiba University of Commerce Review, $52(2), 253-275$.

Hummel, K. (2014). Introducing Second Language Acquisition: Perspectives and practices. Malden, MA: Wiley Blackwell.

Hussain, S., Ahmad, N., Saeed, S., \& Khan, F. N. (2015). Effects of flip learning approach on prospective teacher's pedagogical skills. The Dialogue A Quarterly Research Journal, 10(3), 326-337.

Kang, N. (2015). The comparison between regular and flipped classrooms for EFL Korean adult learners. Multimedia-Assisted Language Learning, 18(3), 41-72.

Kugler, A., Gogineni, H., \& Garavlia, L. (2019). Learning outcomes and student preferences with flipped vs lecture/case teaching model in a block curriculum. American Journal of Pharmaceutical Education, 83(8), 1759-1766. 
Lee, K.-W. (2000). English teachers' barriers to the use of computer-assisted language learning. The Internet TESL Journal, 6(12). Retrieved from http://iteslj.org/Articles/LeeCALLbarriers.html

Long, M. (2015). Second language acquisition and task-based language teaching. West Sussex, UK: Wiley.

McNiff, J., \& Whitehead, J. (2011). All you need to know about action research. London: Sage. Mills, G. E. (2011). Action research: a guide for the teacher researcher (4th ed.). USA: Pearson. Moranski, K., \& Kim, F. (2016). 'Flipping' lessons in a multi-section Spanish course: Implications for assigning explicit grammar instruction outside of the classroom. The Modern Language Journal, 100(4), 830-852.

Nunan, D. (2004). Task-based language teaching. New York: Cambridge University Press.

Oki, Y. (2016). Flipping a content-based ESL course: An action research report. Hawaii Pacific University TESOL Working Paper Series, 14, 62-75.

Prensky, M. (2014). Digital natives, digital inmigrants. On the Horizon, 9(5), 1-6.

Rebuschat, P. (2015). Implicit and explicit learning of languages. Philadelphia: John Benjamins Publishing Company.

Rehman, R., Hashmi, S., Akbar, R., \& Fatima, S. S. (2020). Teaching "shock pathophysiology" by flipped classroom: Views and perspectives. Journal of Medical Education and Curricular Development, 7, 1-4.

Ritchhart, R., Church, M., \& Morrison, K. (2011). Making thinking visible: How to pormote engagement, understanding, and independence for all learners. San Francisco, CA: Jossey-Bass.

Skinner, B. F. (1957). Verbal behavior. New York: Appleton-Century-Crofts. 
Strayer, J. F. (2007). The effects of the classroom flip on the learning environment: A comparison of learning activity in a traditional classroom and a flip classroom that used an intelligent tutoring system. Dissertation, The Ohio State University.

Umam, K., Nusantara, T., \& Mulyono, H. (2019). An application of flipped classroom in mathematics teacher education programme. International Journal of Interactive Mobile Technologies, 13(3), 68-80.

Walton, E. (2019). 20 simple questions to evaluate your lesson. Retrieved from English First Teacher Zone: https://www.ef.com/wwen/blog/teacherzone/20-question-checklistevaluate-lesson/

Webb, M., \& Doman, E. (2016). Does the flipped classroom lead to increased gains on learning outcomes in ESL/EFL context? The Catesol Journal, 28(1), 39-67.

Woolf, B. P., Lane, H. C., Chaudhri, V. K., \& Kolodner, J. L. (2013). AI grand challenges for education. AI Magazine, 34, 66-84.

Yildiz Durak, H. (2018). Flipped learning readiness in teaching programming in middle schools: Modelling its relation to various variables. Journal of Computer Assisted Learning, 34(6), 939-959. 


\section{APPENDIX: SUPLEMENTAL DOCUMENTS}

\section{Teacher's journal}

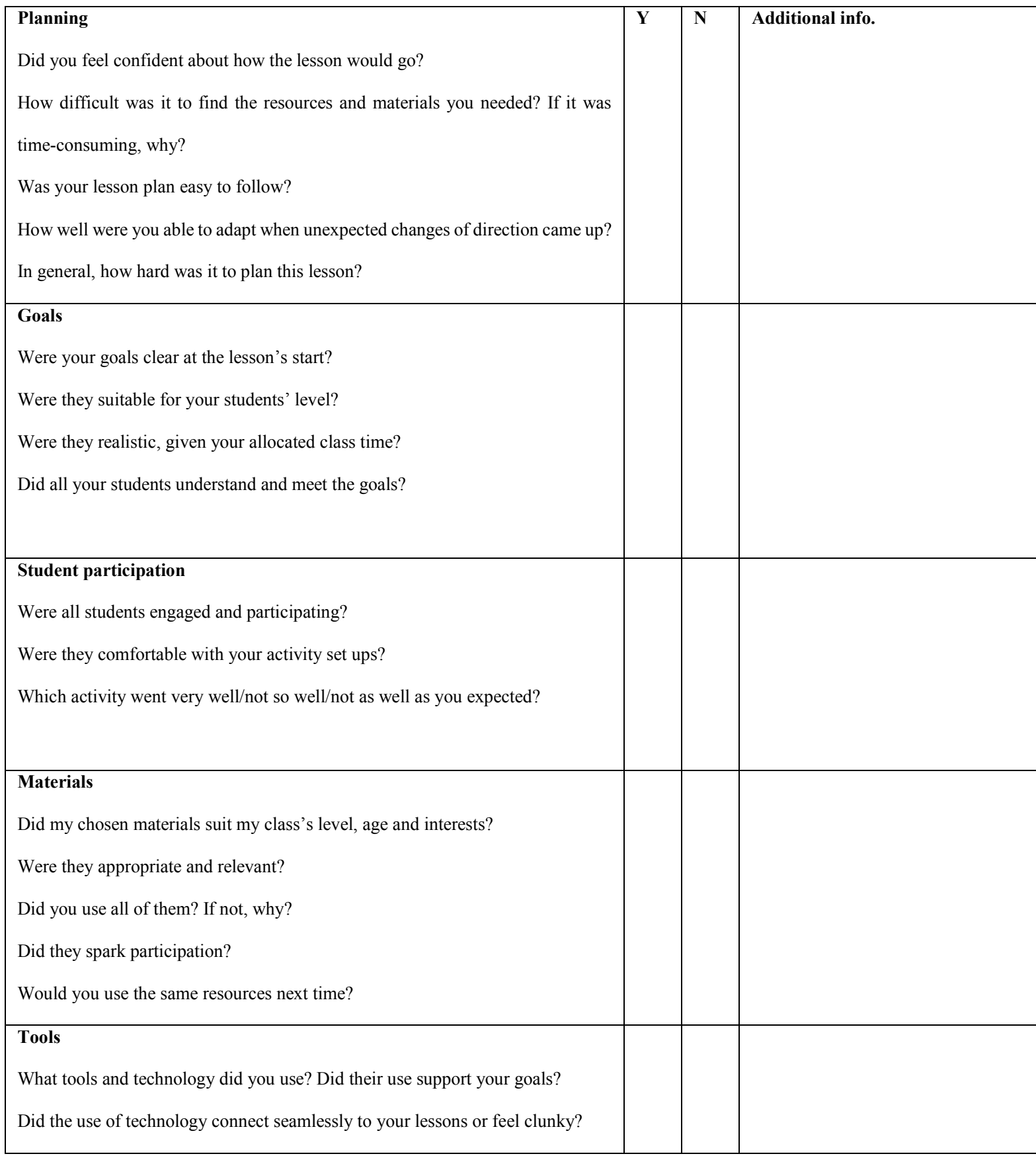




\section{Students' survey}

Please, complete this short questionnaire thinking about the lesson today. All answers are anonymous. I am collecting data for my MA thesis, which is centered around teaching practices in the foreign language classroom. Please, be HONEST

1) Before coming to class today, I watched the corresponding video in MSL (Comprendes)

YES NO

\section{If you answered yes, ....}

....the video I watched before coming to class was very useful in presenting the grammar point.

\begin{tabular}{|l|l|l|l|l|}
\hline Strongly disagree & Disagree & Neither agree nor disagree & Agree & Strongly agree \\
\hline & & & & \\
\hline
\end{tabular}

If you answered no, $\ldots$

....please select what reasons you have for not watching the video for today's lesson. You can select more than one reason.

I did not have time

I forgot

I I did not want to

Not necessary to complete the Comprendes exercise

I I read the textbook grammar sections instead

__ Other, please, explain:

2) Before coming to class today, I completed the corresponding exercise in MSL (Comprendes)

YES NO

\section{If you answered yes, ....}

....the Comprendes exercises I completed before coming to class were very useful to check my understanding of the grammatical point covered in the video.

\begin{tabular}{|l|l|l|l|l|}
\hline Strongly disagree & Disagree & Neither agree nor disagree & Agree & Strongly agree \\
\hline & & & & \\
\hline
\end{tabular}

\section{If you answered no, ....}

....please select what reasons you have for not completing the Comprendes exercises for today's lesson. _ You can select more than one reason.

I did not have time
I forgot
I did not want to
Other, please, explain:

3) The grammar explanation offered in class by the teacher was very useful in helping me understand the grammar. 


\begin{tabular}{|l|l|l|l|l|}
\hline Strongly disagree & Disagree & Neither agree nor disagree & Agree & Strongly agree \\
\hline & & & & \\
\hline
\end{tabular}

If you disagree with the statement in $\# 3, \ldots$

.....please select the reasons why. You may select more than one.

The explanation was confusing

There were not enough examples

The explanation was too long

The explanation was too short

The explanation was too short

__ Other, please, explain:

4) The number of activities we did in class was adequate to help me understand and practice the grammar point.

\begin{tabular}{|l|l|l|l|l|}
\hline Strongly disagree & Disagree & Neither agree nor disagree & Agree & \\
\hline & & & & \\
\hline
\end{tabular}

5) The type of activities we did in class was adequate to help me understand and practice the grammar point.

\begin{tabular}{|l|l|l|l|l|}
\hline Strongly disagree & Disagree & Neither agree nor disagree & Agree & Strongly agree \\
\hline & & & & \\
\hline
\end{tabular}

Please, feel free to add anything about today's lesson in the back of this page, good or bad. Thank you 


\section{Worksheet "el se impersonal"}

Name:

Remember that you must watch the video to answer the questions.

https://www.youtube.com/watch?v=ZWIm345TJk

What is the first use of "se impersonal" mentioned in the video?

What are the example given in the video for the verbs "permitir" and "comprar"?

Conjugate these two verbs with the images on the right.

- Permitir

- Prohibir

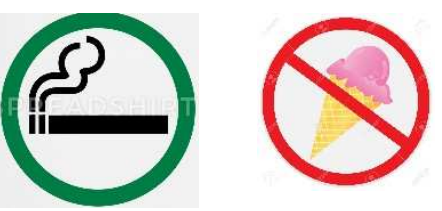

What is the second use of "se impersonal" mentioned in the video?

Translate the following sentences

- $\quad$ A ring was found in the street

- A class is explained online

- Classes are explained online 